\title{
Effects of Conjugated Linoleic Acid and Hilsha Fish Oil (Tenualosa Ilisha) on Alloxan Induced Diabetes Mellitus in Sprague Dawley Rats
}

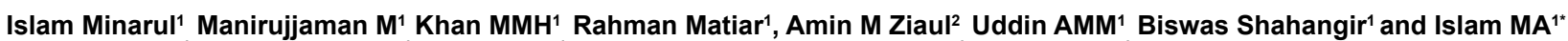

${ }^{1}$ Department of Biochemistry and Molecular Biology, University of Rajshahi, Rajshahi-6205, Bangladesh

${ }^{2}$ Department of Biotechnology and Genetic Engineering, Jessore University of Science and Technology, Jessore, Bangladesh

\begin{abstract}
Diabetes mellitus is a multifarious disease. There is no specific cause for the development of this disease. Fish oil plays important role for the remediation of diabetes mellitus. Conjugated Linoleic Acid (CLA) was synthesized by five steps that included saponification of soybean oil, low temperature crystallization of saturated fatty acid, urea crystallization of oleic acid, alkali isomerization of linoleic acid to CLA and fatty acid analysis. Fish oil was extracted from sun dried fish flesh by $n$-hexane. The rats were divided into five groups. The Group-1 and Group-2 considered as normal and Diabetic Control. Group-3, Group-4 and Group-5 diabetic rats were treated with CLA, Fish oil and Glibenclamide respectively. Diabetes Mellitus (DM) was induced by single intra peritoneal injection of freshly prepared alloxan hydrate $(55 \mathrm{mg} / \mathrm{kg}$ Body Weight of rat) in $0.9 \%$ saline solution. The significant effects $(P<0.001)$ of CLA and fish oil were observed in alloxan-induced diabetic rats to control the blood glucose level within range. Antilipidemic effects of CLA and fish oil were also observed and found to reduce the cholesterol and LDL level whereas increased the HDL level significantly $(P<0.05)$. Like glibenclamide CLA and fish oil had significant effects on the control of alloxan induced diabetes mellitus in Sprague Dawley rats.
\end{abstract}

Keywords: Alloxan; CLA; Diabetic control; Glibenclamide; Hilsha fish

\section{Introduction}

Fish is an essential and irreplaceable food in the rural Bangladeshi diet. Fish play an important role in the Bangladeshi diet, constituting the main and often irreplaceable animal source food in poor rural households [1]. Fish oil contain long chain polyunsaturated fatty acids more specifically Eicosapentaenoic Acid (EPA) and Docosahexaenoic Acid (DHA) which have a great benefit for cardiac health controlling blood glucose, reduction of arterial disease, lowering the risk of cancer etc. [2-25]. Diabetes mellitus is a group of metabolic disease characterized by high blood glucose, that results from absolute or relative deficiencies of insulin secretion which causes damage to the large blood vessels of the heart, brain and legs (macrovascular complications) and damage to the small blood vessels, causing problems in the eyes, kidneys, feet and nerves (microvascular complications) [26]. World Health Organization (WHO) published estimates that the diabetic population is likely to increase to 300 million or more by the year of 2025 . The reason behind this is the adverse effect of all antidiabetic drugs during long term use [27]. Tenualosa ilisha is the national fish of Bangladesh and contributes both to national economy and health. CLA have the antidiabetic effect by mediating insulin release through islet $G$ protein-coupled receptor FFA1/GPR40 [28]. The objectives of this study were to investigate and compare the effects of linoleic acids, extracted from soybean, and hilsha fish (Tenualosa ilisha) to standard glibenclamide on alloxan induced diabetes mellitus in Sprague Dawley rats.

\section{Materials and Methods}

Tenualosa ilisha is essentially a marine water fish but it is abundantly caught in the big and small rivers during July to April. After collection the fish materials were cut into small pieces and sun dried.

\section{Extraction and purification of oil}

Oil was extracted from the dried fish material with $n$-hexane by Soxhlet apparatus and the extracted oil was evaporated under reduced pressure in a rotatory evaporator to obtain oil. The isolated oil was purified by $n$-hexane fractionation method.

\section{Animal maintenance}

Sprague Dawley Rats weighing about 100-150 g were used for experiment. All the animals were kept and maintained under laboratory conditions of temperature $\left(22 \pm 2^{\circ} \mathrm{C}\right)$ and $12 \mathrm{~h}$ day: $12 \mathrm{~h}$ night cycle. They were also allowed to free access of food (standard pellet diet) and water ad libitum. The animals were divided into five groups containing six rats in each group.

\section{Induction of diabetes in rats}

Diabetes mellitus was induced by single intraperitoneal injection of freshly prepared Alloxan Hydrate $(55 \mathrm{mg} / \mathrm{kg}$ body weight) in $0.9 \%$ saline solution. Diabetes was developed and stabilized in these alloxan treated rats over a period of 48 hours. After three days of alloxan administration blood was collected by tail puncture and plasma glucose levels of each rat were determined. Rats with a fasting plasma glucose range of $280-350 \mathrm{mg} / \mathrm{dL}$ were considered diabetic and included in the study.

\section{Treatment schedule}

In experiment, the total number of 30 rats (6 normal; 24 Alloxandiabetic surviving rats) were used. The rats were divided into 5 groups of 6 rats in each group. Group 1 - normal rats treated with vehicle alone (Normal diet). Alloxan induced diabetic rats of Group 2, 3 and

*Corresponding author: Mohammad Amirul Islam Ph.D, M.Sc. (Biochemistry), Professor, Department of Biochemistry and Molecular Biology, University of Rajshahi, Rajshahi-6205, Bangladesh, Tel: + 880-171-2141273; Fax: + 880-721750064; E-mail: maislam06@gmail.com

Received May 13, 2014; Accepted July 27, 2014; Published August 18, 2014

Citation: Minarul I, Manirujjaman M, Khan MMH, Matiar R, Ziaul AM, et al. (2014) Effects of Conjugated Linoleic Acid and Hilsha Fish Oil (Tenualosa Ilisha) on Alloxan Induced Diabetes Mellitus in Sprague Dawley Rats. J Diabetes Metab 5: 412 doi:10.4172/2155-6156.1000412

Copyright: (C) 2014 Minarul I, et al. This is an open-access article distributed under the terms of the Creative Commons Attribution License, which permits unrestricted use, distribution, and reproduction in any medium, provided the original author and source are credited. 
Citation: Minarul I, Manirujjaman M, Khan MMH, Matiar R, Ziaul AM, et al. (2014) Effects of Conjugated Linoleic Acid and Hilsha Fish Oil (Tenualosa Ilisha) on Alloxan Induced Diabetes Mellitus in Sprague Dawley Rats. J Diabetes Metab 5: 412 doi:10.4172/2155-6156.1000412

Page 2 of 4

4 were treated with conjugated linoleic acid ( $1 \%$ of total diet); hilsha fish oil ( $1 \%$ of total diet) and glibenclamide $(0.6 \mathrm{mg} / \mathrm{kg}$ body weight $)$ respectively. Group 5 alloxan-treated diabetic rats were controlled (normal diet) for 15 days.

\section{Sample collection and assessment of serum}

After 15 days of treatment blood specimens were collected from the thoracic artery of the rats after anaesthetization with diethyl ether. For coagulation, blood was kept about 20 minutes at room temperature. After centrifugation at $1600 \mathrm{~g}$ for 15 minutes at $4^{\circ} \mathrm{C}$, serum were drawn off and stored at $-80^{\circ} \mathrm{C}$ until the experiments were performed.

\section{Laboratory examination}

The analyzer (CHEM-5 V3, Erba, Mannheim, Germany) were used for the measurement of serum indices by using commercially available kits according to the manufacture's protocol. Cholesterol, HDL, LDL, triglycerides, urea, uric acid, creatinine, SGPT and SGOT level were

\begin{tabular}{|l|c|c|c|}
\hline Group & $3^{\text {rd }}$ day & $9^{\text {th }}$ day & $14^{\text {th }}$ Day \\
\hline Normal & $91.19 \pm 0.320$ & $91.62 \pm 0.3160$ & $97.103 \pm 0.5894$ \\
\hline Diabetic Control & $342.92 \pm 1.478^{\star}$ & $383.13 \pm 1.365^{\star}$ & $393.36 \pm 1.433^{\star}$ \\
\hline Diabetic+CLA & $333.13 \pm 1.90^{\mathrm{b}^{* *}}$ & $325.81 \pm 2.91^{* *}$ & $329.95 \pm 5.07^{\star *}$ \\
\hline Diabetic+Fish oil & $322.86 \pm 2.145^{\text {a* }}$ & $328.43 \pm 3.290^{\star *}$ & $335.85 \pm 3.47^{\star *}$ \\
\hline Diabetic+Glybenclemide & $294.16 \pm 4.400^{\star *}$ & $310.21 \pm 1.949^{* *}$ & $314.40 \pm 3.98^{* *}$ \\
\hline
\end{tabular}

T Blood glucose level in the treated rats were significantly different from normal and diabetic control groups at $\mathrm{P}<0.001$; $\mathrm{a}: \mathrm{P}<0.005$ and $\mathrm{b}: \mathrm{P}<0.05^{*}$ indicated the difference from normal group; whereas ${ }^{* *}$ indicated the difference from Diabetic control group.

Table 1: Effect of CLA and T.ilisha fish oil on the blood glucose level of experimental rats.

\begin{tabular}{|l|c|c|c|}
\hline Group & Initial & After $7^{\text {th }}$ day & After $15^{\text {th }}$ day \\
\hline Normal & $116.42 \pm 0.51388$ & $121.99 \pm 0.7011$ & $128.20 \pm 0.966$ \\
\hline Diabetic control & $116.0 \pm 1.37246^{\star}$ & $89.37 \pm 1.1302^{\mathrm{a}^{*}}$ & $72.56 \pm 2.18^{\mathrm{a}^{*}}$ \\
\hline Diabetic+CLA & $117.14 \pm 1.4376^{\star *}$ & $86.23 \pm 2.5238^{\mathrm{c}^{* *}}$ & $96.37 \pm 1.9042^{\mathrm{b}^{* *}}$ \\
\hline Diabetic+Fish oil & $116.77 \pm 1.5242^{\star *}$ & $93.21 \pm 3.707^{\mathrm{c}^{* *}}$ & $104.13 \pm 2.93^{\mathrm{b}^{* *}}$ \\
\hline Diabetic+glibenclemide & $111.81 \pm 0.5753^{\star *}$ & $90.28 \pm 1.445^{\mathrm{a}^{* *}}$ & $104.95 \pm 2.509^{\mathrm{a}^{* *}}$ \\
\hline
\end{tabular}

II Body weight in the treated rats were significantly different from normal and diabetic control groups at a: $\mathrm{P}<0.0001 ; \mathrm{b}: \mathrm{P}<0.005$ and $\mathrm{c}$ : $\mathrm{P}<0.05^{*}$ indicated the difference from normal group; whereas ** indicated the difference from Diabetic control group.

Table 2: Effect of CLA and T.ilisha fish oil on rats' body weight. measured by the kits from Human, Germany. All serum samples were analyzed in duplicate and then mean values were taken.

\section{Statistical analysis}

All the results were expressed as mean \pm SEM. Difference between the groups were tested statistically by using independent t-test at $95 \%$ confidence interval. $P<0.05$ was considered as significant.

\section{Results}

\section{Hypoglycemic effect CLA and T.ilisha}

Comparing the blood sugar level in alloxan induced rats, CLA and fish oil administered subject showed significant reduction of blood glucose level at $P<0.001$, which is as near as glibenclamide administered subject at $P<0.001$ (Table 1 ).

\section{Changes in Rat Body weight}

In case of T.ilisha fish oil, the increase in body weight was $43.50 \%$, which was highly significant $(P<0.005)$ than the CLA treatment in which case body weight reduction was $32.81 \%(P<0.005)$. Increase of body weight by T.ilisha fish oil was as near as the glibenclamide treatment $(44.63 \%, P<0.0001)$ (Table 2$)$.

\section{Lipid profile}

$18 \%$ and $21 \%$ reduction of cholesterol $(P<0.01)$ level were observed for CLA and fish oil treatment respectively in diabetic rats whereas in case of glibenclamide, it was $32.64 \%$. LDL level was reduced $(P<0.05)$ for CLA, fish oil and glibenclamide treatment at $16.38 \%, 19.36 \%$ and $23.19 \%$ whereas HDL level was increased significantly $(P<0.05)$ at $23.81 \%, 36.92 \%$ and $45.45 \%$ respectively. A little bit different scenario was observed for triglyceride level. Glibenclamide reduced the triglyceride level more significantly $(38.28 \%, P<0.005)$ than CLA $(16.47 \%, P<0.05)$ and fish oil $(10.94 \%, P<0.05)$. Table 3 represented the change of lipid profile by the administration of CLA, fish oil and glibenclamide in alloxan induced diabetic rats (Table 3 ).

\section{Urea, Uric acid, Creatinine, SGPT and SGOT level}

Urea, uric acid and creatinine level were increased significantly $(P<0.05)$ after diabetic induction. Like glibenclamide, treatment of CLA and fish oil reduced urea level significantly $(P<0.05)$. Significant reduction $(P<0.05)$ of uric acid and creatinine level was also occurred after CLA and fish oil treatment (Table 4).

\begin{tabular}{|c|c|c|c|c|}
\hline Group & Cholesterol & Triglycerides & HDL & LDL \\
\hline Normal & $67.88 \pm 0.9612$ & $71.88 \pm 2.442$ & $49.76 \pm 1.051$ & $84.006 \pm 2.438$ \\
\hline Diabetic Control & $95.53 \pm 1.963^{a^{*}}$ & $108.15 \pm 3.37^{\mathrm{b}^{*}}$ & $43.25 \pm 1.944^{\mathrm{d}^{*}}$ & $119.79 \pm 4.350^{\mathrm{b}^{*}}$ \\
\hline Diabetic+CLA & $78.95 \pm 1.604^{\mathrm{b}^{* *}}$ & $90.33 \pm 2.069^{\mathrm{d}^{* *}}$ & $53.55 \pm 0.5456^{\mathrm{c}^{* *}}$ & $100.25 \pm 5.004^{\mathrm{d}^{* *}}$ \\
\hline Diabetic+Fish oil & $75.50 \pm 2.516^{c^{* *}}$ & $97.02 \pm 1.385^{\mathrm{d}^{* *}}$ & $59.22 \pm 1.366^{\mathrm{b}^{* *}}$ & $96.59 \pm 4.588^{\mathrm{d}^{* *}}$ \\
\hline Diabetic+Glibenclemide & $64.34 \pm 1.818^{\mathrm{a}^{*+}}$ & $66.74 \pm 3.583^{b^{* *}}$ & $62.91 \pm 3.209^{\mathrm{c}^{4+}}$ & $92.01 \pm 2.712^{\mathrm{c}^{*+}}$ \\
\hline
\end{tabular}

TSerum Cholesterol, Triglycerides, HDL and LDL in the treated rats were significantly different from normal and diabetic control groups at a: $P<0.001 ; \mathrm{b}: P<0.005$; $\mathrm{c}: P<0.01$ $\mathrm{d}: P<0.05^{*}$ indicated the difference from normal group; whereas ${ }^{* *}$ indicated the difference from Diabetic control group.

Table 3: Effect of CLA and T. ilisha fish oil on serum Cholesterol, Triglycerides, HDL and LDL on control and experimental rats (mean \pm SEM).

\begin{tabular}{|c|c|c|c|}
\hline Treatment Group & Uric Acid (mg/dl) & Urea (mg/dl) & Creatinine $(\mathrm{mg} / \mathrm{dl})$ \\
\hline Normal & $8.036 \pm 0.3514$ & $31.94 \pm 1.7808$ & $1.15 \pm 0.09615$ \\
\hline Dibetic Control & $16.243 \pm 0.962 a^{*}$ & $55.16 \pm 3.0162^{2 *}$ & $2.55 \pm 0.2826^{\star}$ \\
\hline Diabetic+CLA & $10.58 \pm 0.6904^{* *}$ & $42.23 \pm 2.3531^{* *}$ & $1.63 \pm 0.01767^{* *}$ \\
\hline Diabetic+Fish oil & $11.626 \pm 0.6688^{* *}$ & $45.07 \pm 1.4975^{\star \star}$ & $1.54 \pm 0.15560^{* *}$ \\
\hline Diabetic+Glibenclemide & $9.69 \pm 0.3626^{* *}$ & $34.41 \pm 2.6469^{a * *}$ & $1.00 \pm 0.2343^{* *}$ \\
\hline
\end{tabular}

Iserum Uric acid, Urea and cretinine in the treated rats were significantly different from normal and diabetic control groups at $P<0.05$; a: $P<0.01^{*}$ indicated the difference from normal group; whereas ** indicated the difference from Diabetic control group.

Table 4: Effect of CLA and T. ilisha fish oil on serum Uric acid, Urea and cretinine on control and experimental rats (mean \pm SEM). 
Citation: Minarul I, Manirujjaman M, Khan MMH, Matiar R, Ziaul AM, et al. (2014) Effects of Conjugated Linoleic Acid and Hilsha Fish Oil (Tenualosa llisha) on Alloxan Induced Diabetes Mellitus in Sprague Dawley Rats. J Diabetes Metab 5: 412 doi:10.4172/2155-6156.1000412

\begin{tabular}{|l|c|c|}
\hline Group & SGPT & SGOT \\
\hline Normal & $112.90 \pm 2.771$ & $219.93 \pm 1.66$ \\
\hline Diabetic control & $268.65 \pm 5.705^{\star}$ & $273.35 \pm 6.08^{\mathrm{a}^{*}}$ \\
\hline Diabetic+CLA & $188.47 \pm 3.349^{\star *}$ & $241.04 \pm 1.35^{\mathrm{a}^{* *}}$ \\
\hline Diabetic+Fish oil & $185.37 \pm 3.41^{* *}$ & $136.50 \pm 2.02^{* *}$ \\
\hline Diabetic+Glibenclemide & $155.06 \pm 2.93^{* *}$ & $216.00 \pm 2.94^{* *}$ \\
\hline
\end{tabular}

TIserum SGPT and SGOT in the treated rats were significantly different from normal and diabetic control groups at $P<0.001$; a: $P<0.01^{*}$ indicated the difference from normal group; whereas ${ }^{* *}$ indicated the difference from Diabetic control group.

Table 5: Effect of CLA and T.ilisha fish oil on serum SGPT and SGOT of experimental rats.

There was a significant $(P<0.001)$ increase of SGPT and SGOT level after diabetes induction which was compensated by CLA and fish oil significantly $(P<0.001)$. The reduction of SGPT by CLA and fish oil was $29.84 \%$ and $30.99 \%$ respectively whereas $42.22 \%$ for glibenclamide. The reduction of SGOT level was highly significant for fish oil (50.05\%) than CLA and glibenclamide ( $11.82 \%$ and $20.98 \%$ respectively) (Table 5 ).

\section{Discussion}

Worldwide diabetes mellitus is a common disease; millions of peoples are affected by diabetes. It is a chronic metabolic disorder [29]. The main aim of our study was to estimate the antidiabetic effect of conjugated linoleic acid (CLA) and hilsha fish oil (Tenualosa ilisha) in alloxan induced diabetic rats. Alloxan is a chemical agent which induces diabetes by the destruction of pancreatic beta cells. Low dose $(55 \mathrm{mg} / \mathrm{kg}$ body weight) administation of alloxan causes incomplete destruction of beta cells even though the rats become permanently diabetic [30].

Our present study showed that oral administration of CLA and fish oil decreased blood glucose levels significantly in treated diabetic rats compared with the controlled diabetic rats $(P<0.001)$. The hypoglycemic effect of CLA and fish oil resulted from the enhancement of the production of insulin from the existing beta cells of islets of Langerhans or CLA and fish oil might increase the peripheral uptake of glucose [31]. The plasma glucose lowering activity was compared with glibenclamide, a standard hypoglycemic drug. Glibenclamide had been used for many years to treat diabetes, to stimulate insulin secretion from pancreatic beta cells [32].

The serum glucose data that have obtained clearly indicate that the oral administration of CLA and fish oil produced significant hypoglycemic effect in alloxan induced diabetic rats compared with alloxan induced diabetic control rats.

The results also indicated that CLA and fish oil was more beneficial in the treatment of diabetes as it had hypolipidemic effect. Their hypolipidemic effect could represent a protective mechanism against the development of atherosclerosis, which is usually associated with diabetes.

In our experiment the cholesterol level in CLA, fish oil and glibenclamide treated rats were lower than alloxan induced diabetic control rats. HDL level was significantly increased $(P<0.01)$ following a significant decrease in LDL level $(P<0.05)$ which is an indication of the reduction of the risk of coronary heart diseases that are very common in diabetic patient [33].

The SGOT and SGPT level was increased in diabetic patient as an indication of the liver damage that back to their respective normal level after treatment with CLA, fish oil and glibenclamide that further strengthen the antidiabetic effect of CLA and fish oil. The low level of SGOT and SGPT in CLA and fish oil consuming diabetic rats comparing to control rats indicated the normal function of liver.
Increased serum urea and creatinine levels are significant markers of renal dysfunction in diabetic hyperglycemia which also corrected by the CLA and fish oil treatment in the alloxan induced diabetic rats $(P<0.05)$. This result represented the improved renal function than the diabetic control rats.

From the above discussion we could suggest that Conjugated Linoleic Acid (CLA) and fish oil (Tenualosa ilisha) significantly exert hypoglycemic and hypolipidemic effect on alloxan induced diabetic rats. This investigation showed that CLA and fish oil might contribute in the prevention of diabetes mellitus if used as dietary supplement.

\section{References}

1. Roos N, Islam MM, Thilsted SH (2003) Small indigenous fish species in bangladesh: contribution to vitamin A, calcium and iron intakes. J Nutr 133 : 4021S-4026S

2. Kris-Etherton PM, Harris WS, Appel LJ; American Heart Association Nutrition Committee. (2002) Fish consumption, fish oil, omega-3 fatty acids, and cardiovascular disease. Circulation 106: 2747-2757.

3. Bang HO, Dyerberg J (1980) Lipid metabolism and ischemic heart disease in Greenland Eskimos. In: Draper H, ed. Advances in Nutrition Research. New York, NY: Plenum Press 1:22.

4. Siscovick DS, Raghunathan TE, King I, Weinmann S, Wicklund KG, et al. (1995) Dietary intake and cell membrane levels of long-chain $n-3$ polyunsaturated fatty acids and the risk of primary cardiac arrest. JAMA 274: 1363-1367.

5. Kromhout D, Feskens EJ, Bowles CH (1995) The protective effect of a smal amount of fish on coronary heart disease mortality in an elderly population. In J Epidemiol 24: 340-345

6. Albert CM, Hennekens CH, O'Donnell CJ, Ajani UA, Carey VJ, et al. (1998) Fish consumption and risk of sudden cardiac death. JAMA 279: 23-28.

7. Hu FB, Bronner L, Willett WC, Stampfer MJ, Rexrode KM, et al. (2002) Fish and omega-3 fatty acid intake and risk of coronary heart disease in women. JAMA 287: 1815-1821.

8. Burr ML, Fehily AM, Gilbert JF, Rogers S, Holliday RM, et al. (1989) Effects of changes in fat, fish, and fibre intakes on death and myocardial reinfarction: Die And Reinfarction Trial. Lancet 2: 757-761.

9. (1999) Dietary supplementation with $n-3$ polyunsaturated fatty acids and vitamin E after myocardial infarction: GISSI-Prevenzione trial. Lancet 354: 447-455.

10. Nettleton JA, Katz R (2005) n-3 long-chain polyunsaturated fatty acids in type 2 diabetes: a review. J Am Diet Assoc 105: 428-440.

11. Hornstra, G. The significance of fish and fish-oil enriched food for prevention and therapy of ischaemic cardiovascular disease. Vergroesen, E. G. edn. The Role of Fats in Human Nutrition. 1989:152-235 Academic Press New York, NY

12. Jatoi A (2005) Fish oil, lean tissue, and cancer: is there a role for eicosapentaenoic acid in treating the cancer anorexia/weight loss syndrome? Crit Rev Oncol Hematol 55: 37-43.

13. Wu M, Harvey KA, Ruzmetov N, Welch ZR, Sech L, et al. (2005) Omega-3 polyunsaturated fatty acids attenuate breast cancer growth through activation of a neutral sphingomylinase-mediated pathway. Int J Cancer 117:340-348.

14. Hong MY, Bancroft LK, Turner ND, Davidson LA, Murphy ME, et al. (2005) Fish oil decreases oxidative DNA damage by enhancing apoptosis in rat colon. Nutn Cancer 52:166-175.

15. Suzuki S, Akechi T, Kobayashi M, Taniguchi K, Goto K, et al. (2004) Daily omega-3 fatty acid intake and depression in Japanese patients with newly diagnosed lung cancer. Br J Cancer 90: 787-793.

16. Maillard V, Bougnoux P, Ferrari $P$, Jourdan ML, Pinault M, et al. (2002) N-3 and $\mathrm{N}-6$ fatty acids in breast adipose tissue and relative risk of breast cancer in a case-control study in Tours, France. Int J Cancer 98: 78-83.

17. Karmali RA, Marsh J, Fuchs C (1984) Effect of omega-3 fatty acids on growth of a rat mammary tumor. J Natl Cancer Inst 73: 457-461.

18. Terry PD, Rohan TE, Wolk A (2003) "Intakes of fish and marine fatty acids and the risks of cancers of the breast and prostate and of other hormone-related cancers: a review of the epidemiologic evidence." Am J Clin Nutr 77: 532-543. 
Citation: Minarul I, Manirujjaman M, Khan MMH, Matiar R, Ziaul AM, et al. (2014) Effects of Conjugated Linoleic Acid and Hilsha Fish Oil (Tenualosa llisha) on Alloxan Induced Diabetes Mellitus in Sprague Dawley Rats. J Diabetes Metab 5: 412 doi:10.4172/2155-6156.1000412

Page 4 of 4

19. Mehta SP, Boddy AP, Cook J, Sams V, Lund EK, et al. (2008) Effect of n-3 polyunsaturated fatty acids on Barrett's epithelium in the human lower esophagus. Am J Clin Nutr 87: 949-956.

20. Wolk A, Larsson SC, Johansson JE, Ekman P (2006) Long-term fatty fish consumption and renal cell carcinoma incidence in women. JAMA 296: 13711376

21. Takezaki T, Hirose K, Inoue M, Hamajima N, Yatabe $Y$, et al. (2001) Dietary factors and lung cancer risk in Japanese: with special reference to fish consumption and adenocarcinomas. Br J Cancer 84: 1199-1206.

22. Albino AP, Juan G, Traganos F, Reinhart L, Connolly J, et al. (2000) Cell cycle arrest and apoptosis of melanoma cells by docosahexaenoic acid: association with decreased pRb phosphorylation. Cancer Res 60: 4139-4145

23. Barber MD, Ross JA, Voss AC, Tisdale MJ, Fearon KC (1999) The effect of an oral nutritional supplement enriched with fish oil on weight-loss in patients with pancreatic cancer. $\mathrm{Br} \mathrm{J}$ Cancer 81: 80-86.

24. Gogos CA, Ginopoulos P, Salsa B, Apostolidou E, Zoumbos NC, et al. (1998) Dietary omega-3 polyunsaturated fatty acids plus vitamin E restore immunodeficiency and prolong survival for severely ill patients with generalized malignancy. Cancer 82:395-340.

25. Fernández-Bañares F, Esteve M, Navarro E, Cabré E, Boix J, et al. (1996) Changes of the mucosal $n 3$ and $n 6$ fatty acid status occur early in the colorectal adenoma-carcinoma sequence. Gut 38: 254-259.

26. Patel D, Kumar R, Prasad S, Sairam K, Hemalatha S (2011) Antidiabetic and in vitro antioxidant potential of Hybanthus enneaspermus (Linn) F. Muell in streptozotocin-induced diabetic rats. Asian Pac J Trop Biomed 1: 316-322.

27. Oyedemi SO, Adewusi EA, Aiyegoro OA, Akinpelu DA (2011) Antidiabetic and haematological effect of aqueous exrract of stem bark of Afzelia Africana (Smith) on streptozotocin-induced diabetic Wistar rats. J Asian Pacific Journal of Tropical Biomedicine 1: 353-358.

28. Schmidt J, Liebscher K, Merten N, Grundmann M, Mielenz M, et al. (2011) Conjugated linoleic acids mediate insulin release through islet $\mathrm{G}$ proteincoupled receptor FFA1/GPR40. J Biol Chem 286: 11890-11894.

29. Subash Babu P, Prabuseenivasan S, Ignacimuthu S (2007) Cinnamaldehyde-a potential antidiabetic agent. Phytomedicine 14: 15-22.

30. Aybar MJ, Sánchez Riera AN, Grau A, Sánchez SS (2001) Hypoglycemic effect of the water extract of Smallantus sonchifolius (yacon) leaves in normal and diabetic rats. J Ethnopharmacol 74: 125-132.

31. Tunali S, Yanardag R (2006) Effect of vanadyl sulfate on the status of lipid parameters and on stomach and spleen tissues of streptozotocin-induced diabetic rats. Pharmacol Res 53: 271-277.

32. Eidi A, Eidi M, Darzi R (2009) Antidiabetic effect of Olea europaea L. in normal and diabetic rats. Phytother Res 23: 347-350.

33. Stanely Mainzen Prince P, Menon VP, Gunasekaran G (1999) Hypolipidaemic action of Tinospora cordifolia roots in alloxan diabetic rats. J Ethnopharmaco 64: 53-57. 